\title{
Erratum to: Transoral laser microsurgery for the treatment of oropharyngeal cancer: the Dalhousie University experience
}

\author{
Jonathan C. Melong ${ }^{1 *}$, Matthew H. Rigby ${ }^{1}$, Martin Bullock², Robert D. Hart ${ }^{1}$, Jonathan R.B. Trites $^{1}$ and S. Mark Taylor ${ }^{1}$
}

Unfortunately, the original version of this article [1] contained an error. The names of the authors were included incorrectly and the following sentence was missing from the author's contribution section: "SMT was the research supervisor and assisted with primary data acquisition, analysis and interpretation, and assisted with preparation and revision of the manuscript".

The names and the author's contribution section have been updated in the original article and are also correctly included in full in this erratum.

\begin{abstract}
Authors' contributions
JCM is the corresponding author and was involved in data acquisition, analysis and interpretation, and drafting of the manuscript. MHR was involved in data acquisition, analysis and interpretation and assisted with preparation and revision of the manuscript. MB was involved in tumour pathology characterization and assisted with revision of the manuscript. RDH and JRBT participated in data acquisition and assisted with revision of the manuscript. SMT was the research supervisor and assisted with primary data acquisition, analysis and interpretation, and assisted with preparation and revision of the manuscript. All authors have read and approved the final manuscript.
\end{abstract}

\section{Author details}

'Division of Otolaryngology - Head and Neck Surgery, Queen Elizabeth II Health Sciences Centre and Dalhousie University, Halifax, NS, Canada. ${ }^{2}$ Division of Anatomical Pathology, Queen Elizabeth II Health Sciences Centre and Dalhousie University, Halifax, NS, Canada.

Received: 14 October 2015 Accepted: 14 October 2015

Published online: 21 October 2015

\section{Reference}

1. Melong JC, Rigby MH, Bullock M, Hart RD, Trites J, Taylor SM. Transoral laser microsurgery for the treatment of oropharyngeal cancer: the Dalhousie University experience. J Otolaryngol Head Neck Surg. 2015;44:39.

\footnotetext{
* Correspondence: jonathan.melong@dal.ca

'Division of Otolaryngology - Head and Neck Surgery, Queen Elizabeth II Health Sciences Centre and Dalhousie University, Halifax, NS, Canada

Full list of author information is available at the end of the article
}

\section{Submit your next manuscript to BioMed Central and take full advantage of:}

- Convenient online submission

- Thorough peer review

- No space constraints or color figure charges

- Immediate publication on acceptance

- Inclusion in PubMed, CAS, Scopus and Google Scholar

- Research which is freely available for redistribution 